BIASI, Lourenço; SANTOS, Samuel Martins dos. Prerrogativa de foro e jurisdição constitucional: uma análise em perspectiva histórica das mudanças jurisprudenciais do Supremo Tribunal Federal. Revista Eletrônica Direito e Política, Programa de Pós-Graduação Stricto Sensu em Ciência Jurídica da UNIVALI, Itajaí, v.14, n.1, 10 quadrimestre de 2019. Disponível em: www.univali.br/direitoepolitica - ISSN 1980-7791

\title{
PRERROGATIVA DE FORO E JURISDIÇÃO CONSTITUCIONAL: UMA ANÁLISE EM PERSPECTIVA HISTÓRICA E DA MUDANÇA NA JURISPRUDÊNCIA DO SUPREMO TRIBUNAL FEDERAL
}

\author{
PREROGATIVE OF FORUM AND CONSTITUTIONAL JURISDICTION: AN \\ ANALYSIS IN PERSPECTIVE HISTORICAL AND CHANGE IN THE
}

JURISPRUDENCE OF THE SUPREME FEDERAL COURT

\section{Lourenço Biasi ${ }^{1}$ \\ Samuel Martins dos Santos ${ }^{2}$}

\section{RESUMO}

$\mathrm{O}$ artigo tem como tema o delineamento institucional da prerrogativa de foro nas Constituições brasileiras e do recente posicionamento jurisprudencial sobre a matéria. O problema questiona a ampliação do número de cargos com a prerrogativa a partir de parâmetros republicanos, como também as mudanças da jurisprudência que transformou 0 instituto mais restrito nos últimos anos. A metodologia dedutiva foi utilizada na análise histórica, e indutiva no referente aos casos decididos pelo Supremo Tribunal Federal entre os anos de 2016-2018. Concluímos que a perspectiva histórica comprova uma ampliação substantiva dos cargos abarcados pela prerrogativa de foro, e que tal elemento serviu de base para decisões do Supremo Tribunal Federal mais restritivas a sua incidência, também merecem destaque aspectos formais e materiais das decisões da Suprema Corte que tiveram grande impacto na interpretação do instituto e também nas relações entre o Poder Judiciário e o Poder Legislativo.

PALAVRAS-CHAVE: Prerrogativa de foro; Jurisdição constitucional; imunidade; Supremo Tribunal Federal; Republicanismo.

\footnotetext{
ABSTRACT

The article has as its theme the institutional delineation of the forum prerogative in the Brazilian Constitutions and the jurisprudential changes on the matter. The problem questions the increase in the number of positions with the prerogative from republican parameters, as well as the changes in the jurisprudence that

1 Graduado em Direito pela Faculdade CESUSC, domiciliado em Florianópolis, Santa Catarina. lourencombiasi@hotmail.com

2 Professor de Direito Constitucional da Faculdade CESUSC. Coordenador do Grupo Constituição, democracia \& direitos fundamentais na mesma instituição. Mestre em Teoria e Filosofia do Direito pela Universidade Federal de Santa Catarina. Doutorando em Direito pela Universidade Federal de Santa Catarina. Advogado especialista em Direito Público. OAB/SC. 26.336, domiciliado em São José, Santa Catarina. samuel@wohlkemartins.com.br
} 
BIASI, Lourenço; SANTOS, Samuel Martins dos. Prerrogativa de foro e jurisdição constitucional: uma análise em perspectiva histórica das mudanças jurisprudenciais do Supremo Tribunal Federal. Revista Eletrônica Direito e Política, Programa de Pós-Graduação Stricto Sensu em Ciência Jurídica da UNIVALI, Itajaí, v.14, n.1, $1^{0}$ quadrimestre de 2019. Disponível em: www.univali.br/direitoepolitica - ISSN 1980-7791

transformed the most restricted institute. The deductive methodology was used in the historical analysis, and inductive in the cases decided by the Federal Supreme Court between the years 2016-2018. We conclude that the historical perspective proves a substantive extension of the positions covered by the prerogative of the forum, and that this element served as a basis for decisions of the Federal Supreme Court more restrictive of their incidence, also merit attention to the formal and material aspects of the decisions of the Supreme Court that great impact on the interpretation of the institute and also on the relations between the Judiciary and the Legislative Branch.

KEYWORDS: Prerogative of the forum; Constitutional Jurisdiction; munity; Supreme Court; Republicanism.

\section{INTRODUÇÃO}

No dia 3 de maio de 2018 o Plenário do Supremo Tribunal Federal, por maioria de votos, decidiu alterar a interpretação constitucional sobre foro por prerrogativa de função dos membros do Congresso Nacional.

A prerrogativa de foro é caracterizada como uma regra de competência ratione personae, sendo uma exceção aos demais critérios de fixação da competência do juízo com consequente mitigação do direito à igualdade, pois os titulares dos cargos com prerrogativa de foro não são julgados conforme as regras ordinárias de discriminação da competência processual penal.

A justificativa se ampara no fato de que os titulares de cargos específicos detêm a prerrogativa de serem julgados por tribunais superiores, a fim de resguardar 0 bom desempenho da função, enquanto investida.

Através do presente artigo analisar-se-á os aspectos controvertidos sobre a prerrogativa de foro aos crimes comuns aos congressistas conferida pela Constituição Republicana do Brasil de 1988. Para isso, se buscará ponderar de que forma ocorreu a sua instituição no ordenamento jurídico brasileiro e quais os aspectos formais e materiais que o Supremo Tribunal Federal tem se utilizado para uma interpretação mais restritiva do instituto.

Questiona-se, assim, a instituição do foro por prerrogativa de função é compatível com os postulados do republicanismo contemporâneo? E a decisão do Supremo Tribunal Federal pode ser compreendida como uma reação estratégica às 
BIASI, Lourenço; SANTOS, Samuel Martins dos. Prerrogativa de foro e jurisdição constitucional: uma análise em perspectiva histórica das mudanças jurisprudenciais do Supremo Tribunal Federal. Revista Eletrônica Direito e Política, Programa de Pós-Graduação Stricto Sensu em Ciência Jurídica da UNIVALI, Itajaí, v.14, n.1, $1^{0}$ quadrimestre de 2019. Disponível em: www.univali.br/direitoepolitica - ISSN 1980-7791

interpretações demasiadamente extensivas do instituto e que, por isto, violavam regras básicas do direito a igualdade?

A hipótese do presente artigo é que a ampliação do instituto por prerrogativa de foro não encontra respaldo em ordenamentos jurídicos influentes no Brasil, como também que a interpretação extensiva do instituto proporcionou por muitas décadas um desvirtuamento dos seus objetivos, tendo como referencial normativo o republicanismo contemporâneo. Assim, as decisões do Supremo Tribunal Federal apresentam elementos de adequação do instituto aos postulados republicanos de vieses igualitaristas, ainda que a forma e conteúdo das respectivas decisões possam ser identificados como monocráticas ou demasiadamente centralistas, inclusive em relação ao necessário debate da matéria no Poder Legislativo, que restou prejudicado.

O artigo foi estruturado a partir de três enfoques. No primeiro momento, será abordado os formatos do instituto do foro por prerrogativa de função no Direito Brasileiro, particularmente, em relação as competências do Supremo Tribunal Federal para o julgamento de congressistas. Neste ponto, a metodologia predominante é de perspectiva documental e histórica, analisando como as Constituições Federais brasileiras dispuseram sobre o instituto no decorrer da História Constitucional do Brasil.

O segundo eixo de pesquisa diz respeito aos aspectos controvertidos desta prerrogativa aos congressistas, através das manifestações da doutrina especializada e também de atores relevantes do mundo jurídico.

Na terceira e última parte analisaremos casos paradigmáticos do Supremo Tribunal Federal que tem indicado uma clara tendência de mudança da interpretação da prerrogativa de foro, tornando-o mais restrito na sua incidência em relação aos membros do Poder Legislativo. Nesta parte a metodologia será indutiva, pois a partir das decisões exaradas pelo Poder Judiciário em relação ao Poder Legislativo serão desenvolvidas análises a respeito da configuração da separação dos poderes no Brasil. 
BIASI, Lourenço; SANTOS, Samuel Martins dos. Prerrogativa de foro e jurisdição constitucional: uma análise em perspectiva histórica das mudanças jurisprudenciais do Supremo Tribunal Federal. Revista Eletrônica Direito e Política, Programa de Pós-Graduação Stricto Sensu em Ciência Jurídica da UNIVALI, Itajaí, v.14, n.1, $1^{\circ}$ quadrimestre de 2019. Disponível em: www.univali.br/direitoepolitica - ISSN 1980-7791

\section{A PRERROGATIVA DE FORO NAS CONSTITUIÇÕES BRASILEIRAS: UMA ANÁLISE EM PERSPECTIVA HISTÓRICA}

As análises históricas tendem a perder em profundidade na medida em que se amplia a extensão temporal. Se por um lado este é um risco que se assume no presente tópico, por outro, tal composição pode contribuir para uma análise do instituto em perspectiva, sobretudo, para uma constatação que apenas indicamos agora e que será comprovada no decorrer do tópico.

No Brasil, por vários motivos, ocorreu uma ampliação substantiva dos cargos titulares da prerrogativa de foro. Conforme veremos, as razões foram as mais variadas. No entanto, considerando a premissa que se trata de um instituto excepcional, qualquer ampliação dos cargos que serão submetidos a tal regramento deve receber análise igualmente restritiva, e criteriosa exposição dos seus motivos.

$\mathrm{Na}$ condição de um instituto que mitiga o direito `a igualdade, e visa garantir o bom exercício da função, a prerrogativa de foro ganhará destaque no Direito Público brasileiro a partir da Primeira República.

Assim, em 15 de novembro de 1889, Manoel Deodoro da Fonseca pôs fim à Monarquia no Brasil ao proclamar o regime Republicano de Estado contando com grande apoio por parte da oficialidade do Exército. Com destaque de sua elaboração por Rui Barbosa, a Primeira Constituição Republicana Brasileira teve predominante inspiração na Constituição dos Estados Unidos da América, bem como combinava elementos com formulações constitucionais vigentes na Europa ${ }^{3}$.

Segundo Bonavides, a finalidade da Constituição Republicana consistia em neutralizar o poder pessoal do governante e, tanto quanto possível, distanciar a Sociedade do Estado extinguindo, para isto, títulos nobiliárquicos, ordens

\footnotetext{
${ }^{3}$ Silva Neto, Casimiro Pedro da. A construção da democracia : síntese histórica dos grandes momentos da Câmara dos Deputados, das Assembléias Nacionais Constituintes do Congresso Nacional. Publicador Câmara dos Deputados, Coordenação de Publicações. 2003, p. $278-280$.
} 
BIASI, Lourenço; SANTOS, Samuel Martins dos. Prerrogativa de foro e jurisdição constitucional: uma análise em perspectiva histórica das mudanças jurisprudenciais do Supremo Tribunal Federal. Revista Eletrônica Direito e Política, Programa de Pós-Graduação Stricto Sensu em Ciência Jurídica da UNIVALI, Itajaí, v.14, n.1, $1^{\circ}$ quadrimestre de 2019. Disponível em: www.univali.br/direitoepolitica - ISSN 1980-7791

honoríficas e os privilégios de nascença ou foros de nobreza ${ }^{4}$. Esta intenção, inclusive, restou expressamente consignada no artigo 72 da Constituição de 1891 ao dispor que sobre a igualdade de todos perante a lei, não admitindo mais o foro de nobreza e todas as prerrogativas destes.

Todavia, apesar da expressa abdicação de foro pela Constituição, o Decreto no 848/1890, que organizou a Justiça Federal, atribuiu ao Supremo Tribunal Federal no artigo 9 a competência para julgar originária e privativamente o Presidente da República e os Ministros Diplomáticos nos crimes comuns. O cerne deste regramento foi transcrito pelos artigos 57, § 20 , e 59, I, a e b da Constituição de 1890, acrescidos, ainda, os Ministros de Estado.

A partir da consolidação do modelo republicano de Estado, através das novas Constituições brasileiras, essa prerrogativa acabou por tornar-se mais abrangente, ampliando o número de agentes contemplados, conforme será exposto.

Após a ruptura institucional com a Revolução de 1930 e a instalação de um governo provisório, sobreveio em 16 de Julho de 1934 a promulgação da Constituição da República dos Estados Unidos do Brasil, onde incorporou-se a prerrogativa de foro aos Ministros da Corte Suprema, Ministros do Tribunal de Contas, ao Procurador-Geral da República, bem como aos Juízes dos Tribunais federais e das Cortes de Apelação dos Estados, do Distrito Federal e dos Territórios e Embaixadores.

Pouco mais de três anos, com a Constituição dos Estados Unidos do Brasil de 1937, não houve inovação ao alcance desta prerrogativa em relação ao ordenamento jurídico anterior, uma vez que os dispositivos constitucionais que tratam sobre o tema possuem praticamente o mesmo teor.

4 BONAVIDES, Paulo. A evolução constitucional do Brasil. Revista do Advogado, São Paulo, v. 23, n. 72 , p. 68-76, Out. 2003, p. 259 
BIASI, Lourenço; SANTOS, Samuel Martins dos. Prerrogativa de foro e jurisdição constitucional: uma análise em perspectiva histórica das mudanças jurisprudenciais do Supremo Tribunal Federal. Revista Eletrônica Direito e Política, Programa de Pós-Graduação Stricto Sensu em Ciência Jurídica da UNIVALI, Itajaí, v.14, n.1, $1^{\circ}$ quadrimestre de 2019. Disponível em: www.univali.br/direitoepolitica - ISSN 1980-7791

A Constituição dos Estados Unidos do Brasil de 1946 manteve a prerrogativa aos agentes conferidos pela Constituição de 1937, incorporando neste rol os juízes dos Tribunais Regionais do Trabalho, em seu artigo 101.

Com a Constituição da República Federativa do Brasil de 1967 mantiveram-se as prerrogativas anteriormente analisadas, incrementando-se (todos) os Juízes da Justiça do trabalho, bem como os ministros dos Tribunais Superiores Federais e os chefes de missão diplomática, em seu artigo 114 .

Ainda, através do art. 119, inciso I, alínea 'a', na redação dada pela Emenda Constitucional de 1969, acresceu-se à Corte Suprema o julgamento aos deputados e senadores e ao Vice-Presidente da República.

Em relação ao debate na Assembleia Nacional Constituinte entre 1987 e 1988, no que diz respeito as imunidades dos congressistas, dois elementos, não convergentes, precisam ser considerados.

O primeiro deles diz respeito ao contexto de elaboração do documento, inserido em um momento de transição jurídico-política para o restabelecimento de uma modelo democrático. Em função das experiências recentes, havia uma preocupação de proteger os exercentes de cargos eletivos de eventuais perseguições, como cassação de mandato o que justificou a manutenção e ampliação dos sistemas de imunidade dos congressistas.

No aspecto procedimental é importante destacar que a organização da Assembleia Nacional Constituinte foi concebida sob duas alternativas, um colegiado exclusivo, que depois da elaboração da Constituição deixaria de existir, ou uma sobreposição da Assembleia Constituinte com o Congresso Nacional, sendo a segunda alternativa vitoriosa.

O principal risco da cumulação de funções entre a Assembleia Constituinte e o Congresso Nacional era a pauta corporativa, de modo que houvesse uma tendência de manutenção, ou ampliação das imunidades dos congressistas, não para garantir o melhor exercício da função, mas como um desvirtuamento para a proteção dos próprios congressistas. 
BIASI, Lourenço; SANTOS, Samuel Martins dos. Prerrogativa de foro e jurisdição constitucional: uma análise em perspectiva histórica das mudanças jurisprudenciais do Supremo Tribunal Federal. Revista Eletrônica Direito e Política, Programa de Pós-Graduação Stricto Sensu em Ciência Jurídica da UNIVALI, Itajaí, v.14, n.1, $1^{\circ}$ quadrimestre de 2019. Disponível em: www.univali.br/direitoepolitica - ISSN 1980-7791

Como se pode perceber, o tema prerrogativa de foro dos congressistas é fulcral na compreensão de elementos da democracia representativa no Brasil e desde a década de 80 o mesmo é objeto de discussão e debate público.

Assim, a partir da Constituição Federal de 1988 o Supremo Tribunal Federal deixou de ter competência para apreciar as infrações penais comuns imputadas aos membros dos Tribunais de Justiça dos Estados e do Distrito Federal, bem como os membros do Ministério Público e os prefeitos, cabendo aos respectivos Tribunais o julgamento de seus membros (ressalvada a competência da Justiça Eleitoral), de acordo com o disposto nos artigos 96, III e 108, I a. Da mesma forma, o recém-criado Superior Tribunal de Justiça passou a ser competente para processar e julgar:

a) nos crimes comuns, os Governadores dos Estados e do Distrito Federal, e, nestes e nos de responsabilidade, os desembargadores dos Tribunais de Justiça dos Estados e do Distrito Federal, os membros dos Tribunais de Contas dos Estados e do Distrito Federal, os dos 'Tribunais Regionais Federais, dos Tribunais Regionais Eleitorais e do Trabalho, os membros dos Conselhos ou Tribunais de Contas dos Municípios e os do Ministério Público da União que oficiem perante tribunais" (art. 105, I, a da CF/88).

No atual ordenamento constitucional, foram acrescidos os três Comandantes das Forças Armadas, por força da Emenda Constitucional $n^{\circ} 23$, de 2 de setembro de 1999. E, através da edição da Medida Provisória 2.049-22, de 28.8.2000 e da Medida Provisória no 207, de 13 de agosto de 2004 (convertida na Lei no 11.036/2004), houve a equiparação dos cargos de Advogado Geral da União e do Presidente do Banco do Brasil ao cargo de Ministros de Estado, de modo que estes passaram a gozar da prerrogativa de foro.

Assim, a partir da Constituição de 1988, possuem foro especial por prerrogativa de função reservada ao Supremo Tribunal Federal nas infrações penais comuns: o Presidente da República, o Vice-Presidente, os membros do Congresso Nacional, seus próprios Ministros e o Procurador-Geral da República; os Ministros de Estado e os Comandantes da Marinha, do Exército e da Aeronáutica, os membros dos Tribunais Superiores, os do Tribunal de Contas da União, os chefes de missão 
BIASI, Lourenço; SANTOS, Samuel Martins dos. Prerrogativa de foro e jurisdição constitucional: uma análise em perspectiva histórica das mudanças jurisprudenciais do Supremo Tribunal Federal. Revista Eletrônica Direito e Política, Programa de Pós-Graduação Stricto Sensu em Ciência Jurídica da UNIVALI, Itajaí, v.14, n.1, $1^{0}$ quadrimestre de 2019. Disponível em: www.univali.br/direitoepolitica - ISSN 1980-7791

diplomática de caráter permanentes, o Advogado Geral da União e o Presidente do Banco do Brasil.

A competência para julgamento e inquéritos das ações penais destes agentes são feitas pelas Turmas da Corte, restando ao Plenário a análise de algumas autoridades, como o Presidente da Câmara dos Deputados e o Presidente do Senado e o Presidente da República 5 . Para auxiliar os ministros no processamento das ações penais compete ao ministro relator convocar juízes ou desembargadores para a realização do interrogatório e de outros atos da instrução dos inquéritos criminais e ações penais originárias, na sede do tribunal ou no local onde se deva produzir o ato.

O objetivo deste panorama histórico foi analisar as ampliações de um instituto que deveria ser concebido em caráter de excepcionalidade no modelo republicano, pela mitigação do direito à igualdade inerente à este forma de governo.

Nos gráficos abaixo podemos constatar, de forma sintética, a ampliação dos cargos com prerrogativa de foro nas constituições brasileiras em relação ao tempo:

\footnotetext{
${ }^{5}$ Esta mudança ocorreu em Junho de 2014, a partir da Emenda Regimental no 49 do STF.
} 
BIASI, Lourenço; SANTOS, Samuel Martins dos. Prerrogativa de foro e jurisdição constitucional: uma análise em perspectiva histórica das mudanças jurisprudenciais do Supremo Tribunal Federal. Revista Eletrônica Direito e Política, Programa de Pós-Graduação Stricto Sensu em Ciência Jurídica da UNIVALI, Itajaí, v.14, n.1, 10 quadrimestre de 2019. Disponível em: www.univali.br/direitoepolitica - ISSN 1980-7791

Figura.1.1.

\begin{tabular}{|c|c|c|c|c|}
\hline 1934 & 1937 & 1946 & 1967 & 1988 \\
\hline Presidente & Ministro de Estado & Presidente & Presidente & Presidente \\
\hline Ministros de Estado & Ministros Diplomático & Procurador Geral da República & Vice-Presidente & Vice-Presidente \\
\hline Ministros Diplomáticos & Ministros da Suprema Corte & Ministros de Estado & Procurador Geral da República & Procurador Geral da República \\
\hline Ministros do STF & Ministros do TCU & Ministros Diplomáticos & Ministros de Estado & Ministros de Estado \\
\hline Ministros do TCU & Procurador Geral da Replública & Ministros da Suprema Corte & Ministros Diplomáticos & Ministros da Suprema Corte \\
\hline Procurador Geral da Replública & Juizes dos Tribunais Federais & Juizes do TRT & Ministros das Supremas Cortes & Ministro do Tribunal de Contas \\
\hline Juizes dos Tribunais Federais & Juizes da Corte de Apelação & Juizes do Tribunal Federal & Ministros do TCU & Ministros do TST \\
\hline Juizes das Cortes de Apelação & $\begin{array}{l}\text { Juizes do Distrito Federal e } \\
\text { Territórios }\end{array}$ & $\begin{array}{l}\text { Juizes do Distrito Federal e } \\
\text { Territórios }\end{array}$ & Juizes Federais & Deputados \\
\hline $\begin{array}{l}\text { Juizes do Distrito Federal e } \\
\text { Territórios }\end{array}$ & Embaixadores & Juizes do Tribunal Supremo Militar & Juizes das Cortes de Apelação & Senadores \\
\hline \multirow[t]{8}{*}{ Embaixadores } & & $\begin{array}{l}\text { Chefes de Missão Diplomática de } \\
\text { Caráter Permanente }\end{array}$ & $\begin{array}{l}\text { Chefes de Missões Diplomaticas } \\
\text { de caráter permanente }\end{array}$ & $\begin{array}{l}\text { Chefes de Missões Diplomáticas } \\
\text { de caráter permanente }\end{array}$ \\
\hline & & & Juizes dos TRT & Ministros do STJ \\
\hline & & & Juizes do Trabalho & Ministros do TSM \\
\hline & & & $\begin{array}{l}\text { Juizes do Distrito Federal e } \\
\text { Territórios }\end{array}$ & Comandante da Marinha \\
\hline & & & Deputados & Comandante do Exército \\
\hline & & & Senadores & Comandante da Aeronáutica \\
\hline & & & $\begin{array}{l}\text { Membros dos Tribunais } \\
\text { Superiores da União }\end{array}$ & Advogado Geral da União \\
\hline & & & & Presidente do Banco Central \\
\hline
\end{tabular}

Na figura .1.2 abaixo, que considera a relação entre o número de cargos com prerrogativa de foro em cada constituição brasileira, também é possível assinalar o substantivo aumento ocorrido no período republicano.

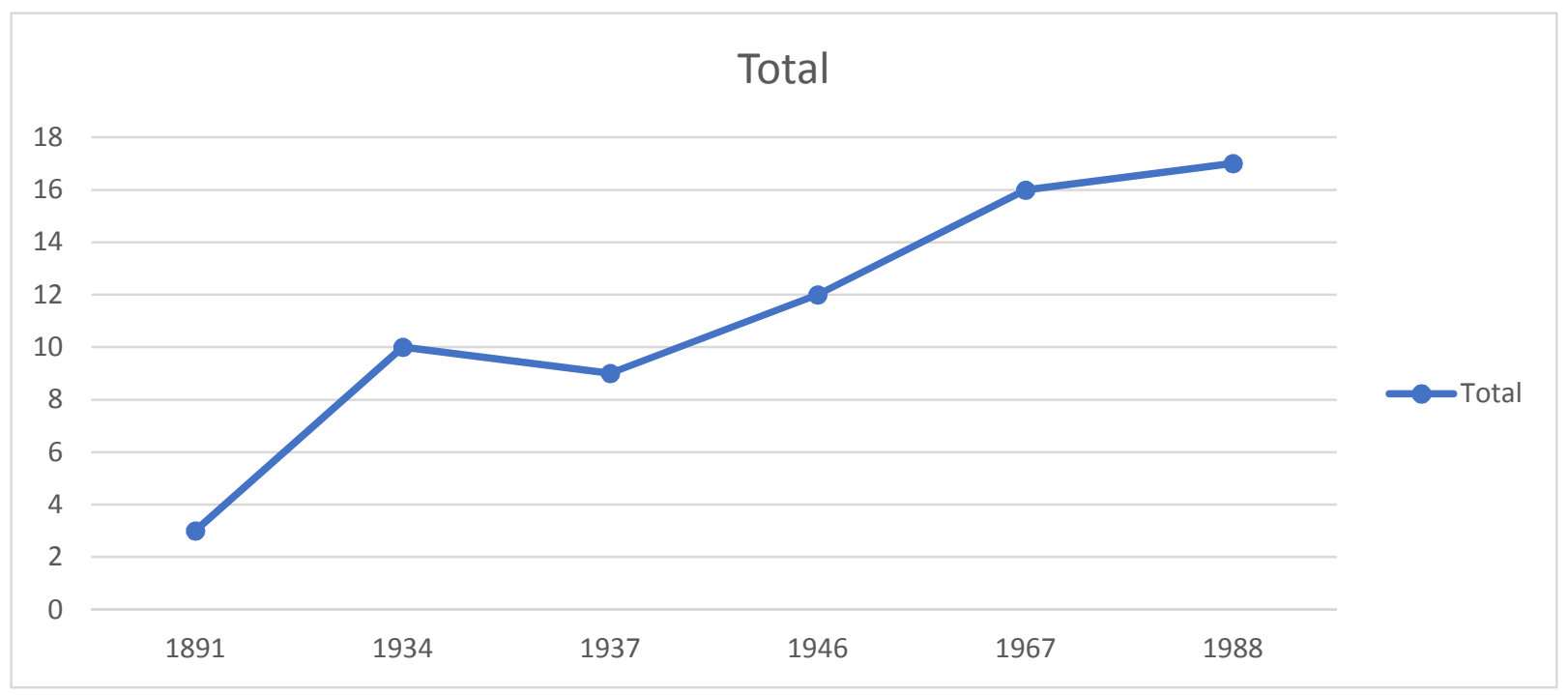


BIASI, Lourenço; SANTOS, Samuel Martins dos. Prerrogativa de foro e jurisdição constitucional: uma análise em perspectiva histórica das mudanças jurisprudenciais do Supremo Tribunal Federal. Revista Eletrônica Direito e Política, Programa de Pós-Graduação Stricto Sensu em Ciência Jurídica da UNIVALI, Itajaí, v.14, n.1, $1^{\circ}$ quadrimestre de 2019. Disponível em: www.univali.br/direitoepolitica - ISSN 1980-7791

O objetivo deste tópico foi fazer uma panorama histórico-institucional da prerrogativa de foro nas Constituições brasileiras, muito mais do que uma simples disposição normativa, tal explanação serve para demonstração da significativa ampliação do instituto ocorrido durante o período republicano, que vai de encontro a necessidade de uma análise restritiva do mesmo.

No próximo tópico, faremos uma sucinta exposição de caráter conceitual sobre republicanismo, buscando nesta referência normativa um suporte para a compreensão da crítica à ampliação dos cargos titulares da prerrogativa de função no Estado brasileiro e de que modo esta configuração obstrui uma adequada efetivação do direito a igualdade.

Posteriormente, analisaremos pontos que são identificados de forma recorrente em relação ao instituto da prerrogativa de foro, para ao fim expor a posição adotada pelo Supremo Tribunal Federal na Ação Penal 937 e no Inquérito 4667, e seus impactos nas relações entre os poderes da república.

\subsection{Republicanismo e prerrogativa de foro: riscos da ampliação demasiada do instituto protetivo ao exercício da função}

As concepções originárias de republicanismo surgem na Roma Antiga, desde então o conceito tem passado por significativas mudanças e acréscimos institucionais, variando a depender do contexto histórico e social ao qual se encontra inserido.

Mesmo nesta amplitude é possível indicar que a concepção de republicanismo se encontra atrelada a vários matizes da vida social, envolvendo tanto questões de caráter institucional, mas também moral e cívico. Genericamente, podemos apresentar como elementos que lhes são inerentes o reconhecimento da existência da coisa pública, e de que a sua gestão deve ser submetida à uma referência de interesse público. Esta construção é elaborada na expectativa de criação de um governo justo e legítimo na relação entre governantes e governados. 
BIASI, Lourenço; SANTOS, Samuel Martins dos. Prerrogativa de foro e jurisdição constitucional: uma análise em perspectiva histórica das mudanças jurisprudenciais do Supremo Tribunal Federal. Revista Eletrônica Direito e Política, Programa de Pós-Graduação Stricto Sensu em Ciência Jurídica da UNIVALI, Itajaí, v.14, n.1, $1^{0}$ quadrimestre de 2019. Disponível em: www.univali.br/direitoepolitica - ISSN 1980-7791

Newton Bignoto apresenta quatro matrizes do republicanismo, a matriz romana e identificada como antiga, e três matrizes que possuem vieses contemporâneos, que são a matriz inglesa, a matriz francesa e a matriz norte americana ${ }^{6}$.

No presente artigo, a principal referência é o republicanismo contemporâneo, marcadamente o matriz francesa e norte-americana, porque além de incorporar a separação entre a coisa pública do patrimônio privado, como também indicar a pertinência da estabilidade do regime político, enfatizou a dimensão deontológica e virtuosa de república e estabeleceu vínculos de tal conceito com os direitos de liberdade e de igualdade.

Segundo Noberto Bobbio, o conceito de República sofreu significante acepção na Idade Moderna com Montesquieu para quem as leis seriam a expressão da vontade popular, com valorização do bem comum e do interesse dos habitantes; com Immanuel Kant ficou referido que a Constituição é responsável por dar forma à Republica na medida que o direito público constituir-se-ia através de um sistema de Leis, para uma pluralidade de homens que, estando numa relação de influência recíproca, necessitariam de um estado jurídico sob uma vontade que fosse responsável pela agregação e unidade do corpo político ${ }^{7}$.

Na Idade Moderna, os ideais Republicanos surgiram como forma de oposição ao absolutismo, pela afirmação de soberania popular, impondo, sobretudo, três importantes características para os chefes de governo: Temporariedade, Eletividade e Responsabilidade ${ }^{8}$.

Na matriz francesa do republicanismo, devemos destacar a relevância da obra de Jean Jacque Rousseuau, que foi responsável pela aproximação do conceito da Teoria Democrática. Neste aspecto, um ponto central na obra de Rousseau foi o

\footnotetext{
${ }^{6}$ BIGNOTTO, Newton . Matrizes do Republicanismo. 1. ed. Belo Horizonte: Editora da UFMG, 2013.

7 BOBBIO, Norberto; MATTEUCCI, Nicola; PASQUINO, Gianfranco (Org.). Dicionário de Política. 5. ed. São Paulo: Imprensa Oficinal do Estado de São Paulo, 2004. 2 v, pg. 1107-1114.

8 STRECK, Lenio Luiz / Morais,Jose Luis Bolzan de: Ciência Política e Teoria do Estado. $8^{a}$ edição. Livraria Do Advogado 2013, p.155.
} 
BIASI, Lourenço; SANTOS, Samuel Martins dos. Prerrogativa de foro e jurisdição constitucional: uma análise em perspectiva histórica das mudanças jurisprudenciais do Supremo Tribunal Federal. Revista Eletrônica Direito e Política, Programa de Pós-Graduação Stricto Sensu em Ciência Jurídica da UNIVALI, Itajaí, v.14, n.1, $1^{0}$ quadrimestre de 2019. Disponível em: www.univali.br/direitoepolitica - ISSN 1980-7791

tripé estabelecido entre republicanismo, virtude e vontade geral, sendo esta última o ponto claro de conexão com o direito a igualdade.

Isto porque a concepção de que todo poder emana do povo apenas seria plausível a partir da referência de que o conceito de povo é formado por indivíduos em condições de igualdade formal, como era interpretado predominantemente naquele contexto.

Alexis de Tocqueville, em meados do ano 1831, ao viajar pela América do Norte, que havia recém adotado o modelo republicano e democrático, destacou a importância da liberdade e - sobretudo - a igualdade das condições como um princípio constitutivo da ordem social democrática e republicana, resultante da vontade de participação, de autonomia dos cidadãos desde os primeiros momentos do processo de colonização, com a fundação das treze colônias. ${ }^{9}$

Neste sentido, concluiu que as leis gerais representam a liberdade coletiva dos cidadãos em se autogovernar através de um acordo livremente consentido caracterizado pela dinâmica entre as partes e do qual os interessados poderiam interferir nos limites de sua obediência ${ }^{10}$.

Atualmente a doutrina contemporânea trabalha o conceito do Neo Republicanismo (ou Republicanismo Neo Romano) a partir do qual uma das razões do Estado Republicano seria justamente garantir a seus cidadãos uma posição de 'não dominação' ao seu próprio poder ${ }^{11}$. Assim, cabe ao Estado percorrer o caminho satisfatório aos interesses comuns assumidos pela sociedade, através de um império de leis, oposta a todos os cidadãos, inclusive aos próprios representantes do Estado ${ }^{12}$.

\footnotetext{
9 TOCQUEVILLE, Alexis: Democracia na América Leis e Costumes. Editora Martins Fontes. São Paulo. Edição 2. Ano 2005, pg. 290-291.

10 TOCQUEVILLE, Alexis: Democracia na América Leis e Costumes. Editora Martins Fontes. São Paulo. Edição 2. Ano 2005, pg. 281.

11 PETTIT, Philip. Teoria da Liberdade. Renato Sérgio Pubo Maciel (Trad). Belo Horizonte: Del Rey, 2007, pg. 211.

12 PETTIT, Philip. Teoria da Liberdade. Renato Sérgio Pubo Maciel (Trad). Belo Horizonte: Del Rey, 2007, pg. 192.
} 
BIASI, Lourenço; SANTOS, Samuel Martins dos. Prerrogativa de foro e jurisdição constitucional: uma análise em perspectiva histórica das mudanças jurisprudenciais do Supremo Tribunal Federal. Revista Eletrônica Direito e Política, Programa de Pós-Graduação Stricto Sensu em Ciência Jurídica da UNIVALI, Itajaí, v.14, n.1, $1^{0}$ quadrimestre de 2019. Disponível em: www.univali.br/direitoepolitica - ISSN 1980-7791

Sobre este ponto, Sérgio Cardoso entende a República como o domínio público de interesse coletivo, regido através de "regime ou império de leis", onde os que "mandam também obedecem", a fim de alcançar a posição de igualdade e liberdade de todos. Deste modo, Cardoso alerta que os governos autocráticos ou hereditários - ainda que eletivos e com leis - jamais alçariam ao status de República, pois a afirmação da cidadania Republicana não se compactuaria com as ideias de prerrogativas e privilégios de extração política, religiosa ou moral ${ }^{13}$.

Com isto podemos assinalar que seja nas matrizes francesa, norte americana ou no neo republicanismo, há um consenso de que os princípios Republicanos consagram que todos os cidadãos são iguais e devem estar sujeitos às mesmas normas. Este princípio também traduz a ideia de responsabilidade político-jurídica de todos os agentes estatais, sem exceção pelos atos que praticarem.

A partir deste viés de caráter normativo e institucional, podemos enfatizar o desregramento da ampliação do instituto da prerrogativa de foro na História Constitucional brasileira, que deveria ser concebido como uma exceção ao direito a igualdade de tratamento por parte de todos os cidadãos.

No Brasil, a instauração da República como "nova forma de governo do Estado nasceu de um movimento de ideias que acompanhou a crise política durante o Segundo Reinado"14 (BONNAVIDES, 2003, pg. 213); este movimento foi motivado não só os ideais republicanos mas também pelo postulado Positivista, pelo fato de ambas linhas de pensamentos serem contrárias às estruturas e a centralização do poder na figura do Sistema Imperatorial ${ }^{15}$.

Todavia, apesar da nova ordem política, as instituições se mostraram incompetentes para romper com a tradição já estabelecida pelos costumes,

13 CARDOSO, Sérgio. Retorno ao Republicanismo. Belo Horizonte: Editora UFMG, 2004, pg. 4647.

14 BONAVIDES, Paulo. A evolução constitucional do Brasil. Revista do Advogado, São Paulo, v. 23, n. 72, p. 68-76., Out. 2003, pg. 213.

15 BONAVIDES, Paulo. A evolução constitucional do Brasil. Revista do Advogado, São Paulo, v. 23, n. 72, p. 68-76., Out. 2003, pg. 217. 
BIASI, Lourenço; SANTOS, Samuel Martins dos. Prerrogativa de foro e jurisdição constitucional: uma análise em perspectiva histórica das mudanças jurisprudenciais do Supremo Tribunal Federal. Revista Eletrônica Direito e Política, Programa de Pós-Graduação Stricto Sensu em Ciência Jurídica da UNIVALI, Itajaí, v.14, n.1, $1^{0}$ quadrimestre de 2019. Disponível em: www.univali.br/direitoepolitica - ISSN 1980-7791

menoridades cívicas, os vícios sociais ingênitos, que faziam a República padecer a desforra do passado.

Na opinião de um destacado jurista do contexto de advento da república no final do século XIX, Sylvio Romero, o Brasil não haveria atingido o desenvolvimento cultural de Nação, o que justificaria que as recém-instituídas instituições republicanas, apesar de serem formadas em um contexto progressista e nos moldes franceses, jamais conseguiram se adequar à realidade do país (ROMERO apud MARTINS, 2006, pg. 102).

Convergindo a este entendimento Sérgio Habib, destaca que a recém implantada República foi um modelo de governo instaurado pelo ideário de poucos que acabou materializando-se pela troca de poder daqueles que já estavam ligados ao Estado, recrudescendo os níveis de corrupção ${ }^{16}$.

O contexto de implantação do instituto da prerrogativa de foro no Brasil, e sua ampliação desmedida, remete a relevante questão apontada por Roberto Schwarcz de reconhece-lo como uma ideia fora do lugar $^{17}$.

Assim, no próximo tópico vamos apresentar algumas questões controvertidas do instituto, que além de ser ampliado de forma desmedida também recebeu interpretação bastante conivente no decorrer das últimas décadas, para ao final analisarmos as novas diretrizes jurisprudenciais do Supremo Tribunal Federal e as características do seu processo de tomada de decisão.

\footnotetext{
16 HABIB, Sérgio. Brasil: quinhentos anos de corrupção: enfoque sócio-histórico-jurídico-penal. Porto Alegre: Sergio Antonio Fabris Editor, 1994. 232 pg. 36.

17 SCHWARZ, Roberto. Cultura na Política. Rio de Janeiro: Paz e Terra, 2001. Pg. 59-84.
} 
BIASI, Lourenço; SANTOS, Samuel Martins dos. Prerrogativa de foro e jurisdição constitucional: uma análise em perspectiva histórica das mudanças jurisprudenciais do Supremo Tribunal Federal. Revista Eletrônica Direito e Política, Programa de Pós-Graduação Stricto Sensu em Ciência Jurídica da UNIVALI, Itajaí, v.14, n.1, 10 quadrimestre de 2019. Disponível em: www.univali.br/direitoepolitica - ISSN 1980-7791

\section{ASPECTOS CONTROVERTIDOS DO FORO POR PRERROGATIVA DE FUNÇÃO: UMA ANÁLISE A PARTIR DO REPUBLICANISMO}

Conforme vimos, no decorrer da História Constitucional do Brasil, a atribuição de foros por prerrogativa atingiu seu paroxismo, incorporando uma quantidade significativa de autoridades.

Em decorrência da quantidade de agentes contemplados, sua manutenção tornouse assunto debatido entre os operadores e doutrinadores do Direito, dividindo opiniões acerca de sua viabilidade e compatibilidade com os princípios republicanos propostos pelas Constituições Brasileiras.

Segundo Renato Brasileiro, a prerrogativa de foro confere a certos agentes a possibilidade de exerce-los em sua plenitude, "com alto grau de autonomia e independência, a partir da convicção de que seus atos, se eventualmente questionados, serão julgados de forma imparcial por um Tribunal" ${ }^{18}$.

Newton Tavares Filho destaca que o foro especial visa assegurar "a imparcialidade dos órgãos judicantes, impedindo o uso indevido do Poder Judiciário em conflitos políticos eleitorais"19. Segundo o autor, não por outra razão "a ditadura militar suspendeu o que então se chamou o "privilégio do foro por prerrogativa de função", como parte do pacote de suspensão de direitos políticos veiculado pelo artigo $5^{\circ}$ do Ato Institucional no $5^{\prime \prime 20}$.

Neste sentido, Jorge Octávio Galvão ${ }^{21}$ destaca que a prerrogativa de foro possui razões pragmáticas para sua existência, pois a exposição midiática inerente a determinados agentes os tornam mais suscetíveis de serem demandados em ações

\footnotetext{
18 LIMA, Renato Brasileiro de. Manual de Processual Penal. Salvador: JusPodivm, 2016, p. 473474.

19 TAVARES FILHO, newton. FORO PRIVIlegiado: PONTOS POSITIVOS E NEGATIVOS. Consultoria Legislativa da Câmara dos Deputados, 2016, pg.1

20 TAVARES FILHO, newton. FORO PRIVILEGIADO: PONTOS POSITIVOS E NEGATIVOS. Consultoria Legislativa da Câmara dos Deputados, 2016, pg.1

21 GALVÃO, José Otávio. Três argumentos para manter o foro por prerrogativa de função. Publicado na Revista Eletrônica Consultor Digital, em 4 de Março de 2017. Disponível em: https://www.conjur.com.br/2017-mar-04/observatorio-constitucional-tres-argumentos-manterforo-prerrogativa-funcao. Acesso em: 30 de Abril de 2018.
} 
BIASI, Lourenço; SANTOS, Samuel Martins dos. Prerrogativa de foro e jurisdição constitucional: uma análise em perspectiva histórica das mudanças jurisprudenciais do Supremo Tribunal Federal. Revista Eletrônica Direito e Política, Programa de Pós-Graduação Stricto Sensu em Ciência Jurídica da UNIVALI, Itajaí, v.14, n.1, $1^{\circ}$ quadrimestre de 2019. Disponível em: www.univali.br/direitoepolitica - ISSN 1980-7791

judiciais de toda ordem. Assim, aponta que a unificação de foro é um mecanismo para atração de uma - possível - gama de processos que possam ser movidos por razões políticas, bem como acabaria por afastar o argumento de que uma futura condenação basear-se-ia em perseguição política por esse ou por aquele magistrado, dada a maior imparcialidade de um órgão plural com superior hierarquia no ordenamento jurídico. Em contrapartida, afirma que o processamento concentrado traria outros benefícios institucionais prejudiciais aos agentes, como o fato de que a uma decisão dirigida ao STF não cabe recurso a outra esfera, limitando a quantidade de protelação processual.

Corroborando este argumento, ao manifestar-se nos autos da Reclamação 473, de $1^{\circ}$ de janeiro de 1964, o ex-ministro Victor Nunes Leal já destacava que a "presumida independência do tribunal de superior hierarquia é, pois, uma garantia bilateral, garantia contra e a favor do acusado"22.

Em outra linha de raciocínio, Bortolon ${ }^{23}$ aponta que a competência do Supremo Tribunal Federal, cuja essência é ser o guardião da Constituição e dirimir questões constitucionais importantes para a sociedade, fica prejudicada com a alta demanda de processos criminais para os quais não possui capacidade dilatória como as de um juiz de primeiro grau.

Ao analisar a prerrogativa por função, em sentido crítico ao instituto, exProcurador-geral da República do Brasil Aristides Alvarenga destaca a deformação aristocrática com que este instituto foi se sedimentando na cultura jurídica brasileira, distinguindo ocupantes de cargos hierarquicamente superiores dos

\footnotetext{
22 SUPREMO TRIBUNAL FEDERAL. Reclamação. Recl. n. 473/GB. Órgão julgador: Tribunal Pleno. Relator: Min. Victor Nunes Leal. Data do julgamento: 31/01/1962. Disponível em: http://redir.stf.jus.br/paginadorpub/paginador.jsp?docTP=AC\&docID=87387 Última visualização em 24 de novembro de 2017 às 01:52. Pg. 25

23 BORTOLON, Vanessa. A restrição do foro por prerrogativa de função e a força normativa da constituição em tempos de lava jato. Disponível em: https://www.conpedi.org.br/publicacoes/27ixgmd9/014I905o/14155UL53BH0OuBz.pdf. Acesso em: 30 de Abril de 2018 p. 10
} 
BIASI, Lourenço; SANTOS, Samuel Martins dos. Prerrogativa de foro e jurisdição constitucional: uma análise em perspectiva histórica das mudanças jurisprudenciais do Supremo Tribunal Federal. Revista Eletrônica Direito e Política, Programa de Pós-Graduação Stricto Sensu em Ciência Jurídica da UNIVALI, Itajaí, v.14, n.1, 10 quadrimestre de 2019. Disponível em: www.univali.br/direitoepolitica - ISSN 1980-7791

demais cidadãos, em total afronta aos princípios basilares republicanos e democráticos ${ }^{24}$.

Para Alvarenga, a falta de consciência popular sobre o poder soberano derivado dos governos republicanos acabou por inverter a essência do foro por prerrogativa de função, uma vez que o instituto foi gerado para garantir autonomia à função pública exercida e não àquele que a exerce ${ }^{25}$.

Neste sentido, já em 2007, a Associação dos Magistrados Brasileiros apresentou ao Conselho Nacional de Justiça estudo com base nas ações propostas em face dos agentes detentores de foro de prerrogativa ao STF entre 15 de dezembro de 1988 (a partir da Ação Penal n0301) e 15 de junho de 2007 (com a Ação Penal n0430), intitulado "Juízes Contra a Corrupção". ${ }^{26}$

Referido estudo concluiu à época a necessidade de serem tomadas ações que pudessem colaborar para a efetiva punição dos crimes cometidos por autoridades com prerrogativa de foro. Na oportunidade, a Associação destacou que a falta de estrutura dos Tribunais brasileiros fez com que "a prerrogativa de foro, ao longo da história, transfigura-se em um inconcebível privilégio recorrentemente utilizado como instrumento de preservação da impunidade" 27.

Mais recentemente, em 2016 (ratificado em 2017), a Fundação Getúlio Vargas produziu estudo público "V Relatório Supremo em números: o foro privilegiado e

\footnotetext{
24 ALVARENGA, Aristides Junqueira: A competência originária do supremo tribunal federal para processo julgamento de crimes. Disponível em: <http://www.migalhas.com.br/depeso/16,mi238162,81042-

+competencia+originaria+do+supremo+tribunal+federal+para+processo+e>. Acesso em: 19 set 2017.

25 ALVARENGA, Aristides Junqueira: A competência originária do supremo tribunal federal para processo e julgamento de crimes. Disponívelem:<http://www.migalhas.com.br/depeso/16,mi238162,81042+competencia+originaria +do+supremo+tribunal+federal+para+processo+e>. Acesso em: 19 set 2017.

AMB, Associação dos Magistrados Brasileiros, "Juízes Contra a Corrupção", 2007. Disponível em https://www.oas.org/juridico/PDFs/mesicic4 bra stf.pdf . Último acesso em 01/06/2018.

${ }^{27}$ ALVARENGA, Aristides Junqueira: A competência originária do supremo tribunal federal para processo e julgamento de crimes. Disponível em: <http://www.migalhas.com.br/depeso/16,mi238162,81042-

+competencia+originaria+do+supremo+tribunal+federal+para+processo+e>. Acesso em: 19 set 2017, pg. 27.
} 
BIASI, Lourenço; SANTOS, Samuel Martins dos. Prerrogativa de foro e jurisdição constitucional: uma análise em perspectiva histórica das mudanças jurisprudenciais do Supremo Tribunal Federal. Revista Eletrônica Direito e Política, Programa de Pós-Graduação Stricto Sensu em Ciência Jurídica da UNIVALI, Itajaí, v.14, n.1, $1^{0}$ quadrimestre de 2019. Disponível em: www.univali.br/direitoepolitica - ISSN 1980-7791

o Supremo", também apontando os baixos índices de condenação pelos Tribunais Superiores $^{28}$. A pesquisa constatou que, entre os anos de e 2002 a 2016, apenas 0,52\% (intervalo de confiança: $0 \%-1,15 \%$ ) dos processos e inquéritos imputados aos réus detentores de foro por prerrogativa geraram condenações, bem como que duas de cada três ações penais o mérito da acusação sequer chegou a ser avaliado pelo Supremo, em razão do declínio de competência ou da prescrição ${ }^{29}$.

Corroborando os dados destas pesquisas, o próprio Supremo Tribunal, pela sua Assessoria de Gestão Estratégica (dados de 22.02.2017), constatou que desde o ano de 2002 houve mais de 200 casos de prescrição da pretensão punitiva em ações penais e inquéritos perante a Corte. ${ }^{30}$

Assim percebe-se que, apesar do foro por prerrogativa de função possuir fundamentos razoáveis e sólidos para sua instituição, a gradual elevação do rol de agentes contemplados vem sendo correlacionada a uma cultura aristocrática em relação a determinados agentes públicos, acarretando o sentimento de impunidade da classe política, pela falta de métodos eficazes no seu julgamento.

Pode-se, pois, afirmar que são aproximadamente 858 (oitocentos e cinquenta e oito) cargos públicos cujos titulares possuem foro por prerrogativa de função junto ao Supremo Tribunal Federal. Destes, mais da metade ocorre em relação aos congressistas, que atingem o número de 594 (quinhentos e noventa e quatro) agentes com prerrogativa de foro perante a Corte Suprema (513 deputados federais e 81 senadores).

\footnotetext{
${ }^{28}$ FALCÃO, J. et al. V Relatório Supremo em Números: o foro privilegiado. Rio de Janeiro: Escola de Direito do Rio de Janeiro da Fundação Getúlio Vargas, 2017. Disponível em: .http://bibliotecadigital.fgv.br/dspace/handle/10438/18097. Último acesso em 05/06/2018

${ }^{29}$ FALCÃO, J. et al. V Relatório Supremo em Números: o foro privilegiado. Rio de Janeiro: Escola de Direito do Rio de Janeiro da Fundação Getúlio Vargas, 2017. Disponível em: .http://bibliotecadigital.fgv.br/dspace/handle/10438/18097. Último acesso em 05/06/2018, pg. 77.

30 SUPREMO TRIBUNAL FEDERAL. Reclamação. QO na AP 937. Voto do Min. Luís Roberto Barroso. Data do julgamento: 31/01/1962, Pg. 9. Disponível em: https://www.conjur.com.br/dl/votobarroso-foro-especial.pdf última visualização em 01/06/2018.
}

pg. 9. 
BIASI, Lourenço; SANTOS, Samuel Martins dos. Prerrogativa de foro e jurisdição constitucional: uma análise em perspectiva histórica das mudanças jurisprudenciais do Supremo Tribunal Federal. Revista Eletrônica Direito e Política, Programa de Pós-Graduação Stricto Sensu em Ciência Jurídica da UNIVALI, Itajaí, v.14, n.1, $1^{0}$ quadrimestre de 2019. Disponível em: www.univali.br/direitoepolitica - ISSN 1980-7791

Em relação aos congressistas, estabelece nosso ordenamento jurídico que, desde a expedição do mandato cabe ao Supremo Tribunal Federal processar e julgar os Deputados e Senadores por crimes comuns e de responsabilidade. Este instituto é previsto em dispositivo constitucional e infraconstitucional, respectivamente no $\S 10$ do artigo 53, na alínea 'a' inciso I artigo 102 da Constituição Federal e no artigo 84 do Código de Processo Penal, na redação dada pela Lei 10.628/02.

Estas garantias estão limitadas ao tempo do exercício das funções do qual está imbuído o agente, pois, conforme assevera o doutrinador Osmar Veronese: "Por representar uma exceção ao princípio da igualdade de todos perante a lei, deve sofrer uma interpretação restritiva, sob pena de revelar-se num odioso privilégio a serviço da impunidade"31

Para Belém ${ }^{32}$, apesar de haver uma cumplicidade de cunho objetivo em prol do antigo privilégio de caráter pessoal e o instituto da prerrogativa de função, explicada pelas raízes do processo histórico e antropológico vivenciado pelo homem brasileiro - fatores estes que propiciam críticas e, principalmente, reflexões sobre a sua extinção -, é essencial que se defina o foro por prerrogativa de função como uma garantia constitucional reservada às autoridades mais importantes da República, tal qual disposta no ordenamento jurídico comparado.

Desta forma, apresentados os aspectos controversos sobre a prerrogativa de foro aos congressistas na prática de crimes comuns, passamos a analisar de que forma este instituto se delineou na jurisprudência do Supremo Tribunal Federal.

\footnotetext{
31 Osmar. Impunidade parlamentar. Revista dos Tribunais, São Paulo, v. 91, n. 797, p. 469. 2002.

32 BELÉM, Orlando Carlos Neves. Do Foro Privilegiado à Prerrogativa de Função. Dissertação de Mestrado. Rio de Janeiro: PUC-Rio, 2008. Disponível
} http://livros01.livrosgratis.com.br/cp077263.pdf>. Acesso em: 26 set 2017, p. 158 
BIASI, Lourenço; SANTOS, Samuel Martins dos. Prerrogativa de foro e jurisdição constitucional: uma análise em perspectiva histórica das mudanças jurisprudenciais do Supremo Tribunal Federal. Revista Eletrônica Direito e Política, Programa de Pós-Graduação Stricto Sensu em Ciência Jurídica da UNIVALI, Itajaí, v.14, n.1, 10 quadrimestre de 2019. Disponível em: www.univali.br/direitoepolitica - ISSN 1980-7791

\section{MUDANÇAS NA INTERPRETAÇÃO SOBRE PRERROGATIVA DE FORO PELO SUPREMO TRIBUNAL FEDERAL}

A discussão por seus próprios ministros sobre a amplitude da prerrogativa do foro no Supremo Tribunal Federal não é recente, em 2012 o Ministro Celso de Mello já manifestou uma posição mais extremada, contrária a toda e qualquer prerrogativa de foro, como também outra posição que restringia a prerrogativa de foro a atos praticados durante o exercício do mandato, ou por decorrência dele. ${ }^{33}$

Recentemente, um membro que tem se destacado na defesa da necessidade de reformas sobre o instituto da prerrogativa de foro é o Ministro Luís Roberto Barroso. Em duas oportunidades nas quais foi relator, as críticas ao instituto e apontamentos sobre possibilidade de seu aperfeiçoamento foram centrais no voto.

Assim, na parte final do presente artigo, vamos analisar a Ação Penal 937, com voto proferido em 2017, e o Inquérito Policial 4667, com voto proferido em 2018. Consideramos que os votos do Ministro Luís Roberto Barroso indicam inegável tendência de interpretação mais restritiva do instituto da prerrogativa de foro. $E$, pelos votos já proferidos nas respectivas ações, há fortes elementos para se supor que tal interpretação mais restritiva tornar-se-á predominante no Supremo Tribunal Federal.

A Ação Penal 937 tem como réu o Deputado Federal Marcos da Rocha Mendes, o mesmo já havia ocupado vários cargos, tanto no Poder Executivo municipal no Estado do Rio de Janeiro, quanto no Poder Legislativo Federal. Em função da sua carreira política, e dos inúmeros deslocamentos de competência, a ação penal em análise encontrava na iminência da prescrição, motivo pelo qual o debate em torno da prerrogativa de foro foi imprescindível.

Após o relato dos inúmeros deslocamentos de competência da citada ação penal, o Ministro Luís Roberto Barroso expressou seu inconformismo com o atual modelo: "O sistema é feito para não funcionar. Mesmo quem defende a ideia de que o foro

\footnotetext{
33 Ministro do STF defende o fim do foro privilegiado. Folha de São Paulo. São Paulo, Especial, p. 8
} 26 de fevereiro de 2012. 
BIASI, Lourenço; SANTOS, Samuel Martins dos. Prerrogativa de foro e jurisdição constitucional: uma análise em perspectiva histórica das mudanças jurisprudenciais do Supremo Tribunal Federal. Revista Eletrônica Direito e Política, Programa de Pós-Graduação Stricto Sensu em Ciência Jurídica da UNIVALI, Itajaí, v.14, n.1, $1^{0}$ quadrimestre de 2019. Disponível em: www.univali.br/direitoepolitica - ISSN 1980-7791

por prerrogativa de função não é um mal em si, na sua origem e inspiração, não tem como deixar de reconhecer que, entre nós, ele se tornou uma perversão da Justiça." 34

Após indicar a existência do problema, o relator aponta as disfunções de um Tribunal Constitucional se dedicar a procedimentos que são afeitos à primeira instância, resultado em grande prejuízo para a qualidade da prestação jurisdicional e deficiência do poder punitivo do Estado:

As estatísticas evidenciam o volume espantoso de feitos e a ineficiência do sistema. Tramitam atualmente perante 0 Supremo Tribunal Federal um número próximo a 500 processos contra parlamentares (357 inquéritos e 103 ações penais)[1]. O noticiário sugere que este número vai aumentar expressivamente. O prazo médio para recebimento de uma denúncia pelo STF é de 565 dias. Um juiz de $1^{\circ}$ grau a recebe, como regra, em menos de uma semana, porque 0 procedimento é muito mais simples. Desde que o STF começou a julgar efetivamente ações penais (a partir da EC $35 / 2001$, que deixou de condicionar ações contra parlamentares à autorização da casa legislativa), já ocorreram mais de seis dezenas de casos de prescrição da pretensão punitiva. A prescrição se dá, como é sabido, pelo decurso de prazo excessivo entre o fato criminoso e a atuação do Estado em puni-lo. ${ }^{35}$.

Na Ação Penal 937 o Ministro Luis Roberto Barroso suscitou questão de ordem para defender uma interpretação mais restritiva do instituto da prerrogativa de foro, de modo a limitar-se aos crimes praticados no exercício da função, ou por decorrência dela. Segundo o próprio, trata-se da interpretação mais condizente com a observância do princípio republicano e o princípio da igualdade.

\footnotetext{
34 SUPREMO TRIBUNAL FEDERAL. Ação Penal. AP. n. 937. Órgão julgador: Primeira Turma. Relator: Min. Luís Roberto Barroso. Data do início do julgamento: 31/05/2017. Disponível em: http://portal.stf.jus.br/processos/detalhe.asp?incidente=4776682última visualização em 01 de junho de 2018 às 17:42, p. 2.

35 SUPREMO TRIBUNAL FEDERAL. Ação Panal. AP. n. 937. Órgão julgador: Primeira Turma. Relator: Min. Luís Roberto Barroso. Data do início do julgamento: 31/05/2017. Disponível em: http://portal.stf.jus.br/processos/detalhe.asp?incidente=4776682Última visualização em 01 de junho de 2018 às 17:42, p. 4.
} 
BIASI, Lourenço; SANTOS, Samuel Martins dos. Prerrogativa de foro e jurisdição constitucional: uma análise em perspectiva histórica das mudanças jurisprudenciais do Supremo Tribunal Federal. Revista Eletrônica Direito e Política, Programa de Pós-Graduação Stricto Sensu em Ciência Jurídica da UNIVALI, Itajaí, v.14, n.1, $1^{0}$ quadrimestre de 2019. Disponível em: www.univali.br/direitoepolitica - ISSN 1980-7791

Importa destacar que dos oito Ministros presentes, seis foram favoráveis integralmente as propostas feitas pelo Ministro Luis Roberto Barroso, com exceção do Ministro Alexandre de Moraes e o Ministro Dias Toffoli, responsável pelo pedido de vista, tal fato foi determinante para que o tema voltasse à discussão no Inquérito 4667, com início de julgamento em 2018.

Segundo o Ministro Luis Roberto Barroso, que também é relator do inquérito policial que tem como réu o Deputado Federal Beto Mansur, a prerrogativa de foro é um sinal de atraso institucional do ordenamento jurídico brasileiro:

Há uma visão atrasada que ainda prevalece em alguns espaços da vida brasileira de que quanto mais competências se têm, maior a quantidade de poder. Nesta visão, o poder não é uma forma de fazer o bem e promover justiça, mas um instrumento para proteger os amigos e perseguir os inimigos. Já é boa hora de se superarem os ciclos do atraso institucional e existencial no Brasil. ${ }^{36}$

Posteriormente, o relator apresenta uma proposta institucional que envolveria um número significativo de alterações legislativas, com mudanças de regras de competência, processo de escolha, sem desconsiderar que

No tocante ao foro, a solução que tenho proposto, de longa data, é a de criação de um juízo especializado de $1^{\circ} \mathrm{grau}$, no Distrito Federal, com juiz titular escolhido pelo Supremo Tribunal Federal. O magistrado teria mandato de quatro anos, ao final dos quais seria automaticamente promovido para o seu tribunal. De suas decisões, caberia recurso para o Supremo Tribunal Federal ou para o Superior Tribunal de Justiça. Juristas ilustres, como Miguel Reale Junior e Pierpaolo Bottini têm proposto solução alternativa, em que a competência seria de um dos cinco Tribunais Regionais Federais, conforme o caso

\footnotetext{
36 SUPREMO TRIBUNAL FEDERAL. Inquérito Policial. IP. n. 4667. Órgão julgador: Primeira Turma. Relator: Min. Luís Roberto Barroso. Data do início do julgamento: 07/02/2018. Disponível em: http://portal.stf.jus.br/processos/detalhe.asp?incidente=5341961, visualização em 01 de junho de 2018 às $17: 42$, p. 4.
} 
BIASI, Lourenço; SANTOS, Samuel Martins dos. Prerrogativa de foro e jurisdição constitucional: uma análise em perspectiva histórica das mudanças jurisprudenciais do Supremo Tribunal Federal. Revista Eletrônica Direito e Política, Programa de Pós-Graduação Stricto Sensu em Ciência Jurídica da UNIVALI, Itajaí, v.14, n.1, $1^{0}$ quadrimestre de 2019. Disponível em: www.univali.br/direitoepolitica - ISSN 1980-7791

Com isto, podemos resumir a posição indicada pelos dois votos do Ministro Barroso, na Ação Penal 937, e no Inq. 4667, a seguinte mudança interpretativa em relação ao instituto da prerrogativa de foro:

1) O foro por prerrogativa de função aplica-se apenas aos crimes cometidos durante o exercício do cargo e relacionados às funções desempenhadas.

2) Após o final da instrução processual, com a publicação do despacho de intimação para apresentação de alegações finais, a competência para processar e julgar as ações penais não será mais afetada em razão de o agente público vir a ocupar outro cargo ou deixar o cargo que ocupava, qualquer que seja o motivo.

Trata-se de uma mudança significativa em relação a posição anterior com base na jurisprudência anterior, conforme precedente firmado na Questão de Ordem no Inquérito 687 (Rel. Min. Sydney Sanches, j. 25.08.1999), esta muito mais ampla e passível de estender a prerrogativa de foro inclusive para atos imputados como crimes anteriores a posse do congressista.

O Inquérito 4667 possui elementos procedimentais que merecem atenção, pois nele ocorreu o envio do processo à primeira instância pelo relator Ministro Luis Roberto Barroso mesmo antes da conclusão ou deliberação de uma questão de ordem específica, com base no argumento de que as teses por uma interpretação restritiva do instituto já se encontravam com 6 (seis) votos dos ministros do Plenário do Supremo Tribunal Federal, isto é, uma maioria expressiva.

Também chama a atenção a pró-atividade do Supremo Tribunal Federal em relação a uma temática diretamente relacionada ao funcionamento e organização do Poder Legislativo. ${ }^{37}$

\footnotetext{
37 Vale destacar que o Superior Tribunal de Justiça já deu claros sinais de que seguirá a nossa tendência jurisprudencial supracitada, quando na Ação Penal 857 e na Ação Penal 866, no dia 20 de junho de 2018, o Superior Tribunal de Justiça decidiu que tanto os governadores quando ministros dos tribunais de contas gozam de prerrogativa de foro apenas por fatos ocorridos durante o exercício do cargo, ou em razão dele.
} 
BIASI, Lourenço; SANTOS, Samuel Martins dos. Prerrogativa de foro e jurisdição constitucional: uma análise em perspectiva histórica das mudanças jurisprudenciais do Supremo Tribunal Federal. Revista Eletrônica Direito e Política, Programa de Pós-Graduação Stricto Sensu em Ciência Jurídica da UNIVALI, Itajaí, v.14, n.1, $1^{\circ}$ quadrimestre de 2019. Disponível em: www.univali.br/direitoepolitica - ISSN 1980-7791

Com isto destacamos a existência de elementos suficientes para a defesa da hipótese de que a jurisprudência brasileira tende para intepretações mais restritivas do instituto da prerrogativa de foro.

\section{CONSIDERAÇÕES FINAIS}

A temática da presente pesquisa foi a imunidade formal, no que diz respeito a prerrogativa de foro, instituto que excepciona as regras ordinárias de discriminação da competência em matéria penal e processual penal os titulares de determinados cargos da República Federativa do Brasil.

Inicialmente, foi ressaltado o vínculo da prerrogativa de foro com uma concepção protetiva do exercício do cargo eletivo, de modo a justificar sua exceção ao princípio da igualdade.

Em perspectiva histórica, foram expostos todos os cargos contemplados pela prerrogativa de foro nas Constituições brasileiras. Conforme foi possível comprovar, o instituto ampliou-se de forma significativa, não apresentando nenhuma época com diminuição dos cargos contemplados. Também é possível indicar que tal ampliação envolveu os três poderes da organização do Estado brasileiro.

Com vistas à um aprofundamento teórico, o trabalho apresentou elementos do conceito de republicanismo e do seu vínculo com o direito a igualdade, de modo a apontar a imprecisão da ampliação desregrada do instituto da prerrogativa de foro na História do Direito Constitucional do Brasil.

Posteriormente, o trabalho apresentou argumentos favoráveis e contrários ao instituto, inclusive apresentados por membros do Supremo Tribunal Federal. E a insatisfação crescente pela inoperabilidade dos seus objetivos, sendo algumas vezes analisados como um mecanismo para dificultar o processamento e punição dos eventuais envolvidos.

A partir de 2017 é possível indicar um aumento do debate em torno do instituto, sobretudo, pelas análises do ministro do Supremo Tribunal Federal, Luis Roberto 
BIASI, Lourenço; SANTOS, Samuel Martins dos. Prerrogativa de foro e jurisdição constitucional: uma análise em perspectiva histórica das mudanças jurisprudenciais do Supremo Tribunal Federal. Revista Eletrônica Direito e Política, Programa de Pós-Graduação Stricto Sensu em Ciência Jurídica da UNIVALI, Itajaí, v.14, n.1, $1^{\circ}$ quadrimestre de 2019. Disponível em: www.univali.br/direitoepolitica - ISSN 1980-7791

Barroso, tais prenúncios resultaram em uma significativa guinada jurisprudência muito mais restritiva ao instituto da prerrogativa de foro.

Conforme exposto pelo Min. Barroso no Inquérito de n. 4667 e na Ação Penal de n 937 a nova interpretação visa reequilibrar uma interpretação abusiva da prorrogativa de foro de modo a violar o direito a igualdade.

O procedimento de tomada de decisão merece atenção, inclusive para servir de questionamento futuro se este caso poder-se-ia ser caracterizado como uma posição ativista do Supremo Tribunal Federal em relação ao Congresso Nacional. Isto porque a matéria, em razão do seu conteúdo, é muito mais afeita aos debates no próprio Poder Legislativo.

O trabalho foi desenvolvido na esteira do debate doutrinário e jurisprudencial sobre a prerrogativa de foro, indicando possibilidades muito pertinentes para 0 desenvolvimento de outras pesquisas científicas.

\section{REFERENCIAS DAS FONTES CITADAS}

ALVARENGA, Aristides Junqueira: A competência originária do supremo tribunal federal para processo e julgamento de crimes. Disponível em: $<$ http://www.migalhas.com.br/depeso/16,mi238162,81042-

+competencia+originaria+do+supremo+tribunal+federal+para+processo+e $>$. Acesso em: 19 set 2017.

BELÉM, Orlando Carlos Neves. Do Foro Privilegiado à Prerrogativa de Função. Dissertação de Mestrado. Rio de Janeiro:_PUC-Rio, 2008.

BIGNOTTO, Newton. Matrizes do Republicanismo. 1. ed. Belo Horizonte: Editora da UFMG, 2013.

BOBBIO, Norberto; MATTEUCCI, Nicola; PASQUINO, Gianfranco (Org.). Dicionário de Política. 5. ed. São Paulo: Imprensa Oficinal do Estado de São Paulo, 2000. 2 v.

BONAVIDES, Paulo. A evolução constitucional do Brasil. Revista do Advogado, São Paulo, v. 23, n. 72. 2003. 
BIASI, Lourenço; SANTOS, Samuel Martins dos. Prerrogativa de foro e jurisdição constitucional: uma análise em perspectiva histórica das mudanças jurisprudenciais do Supremo Tribunal Federal. Revista Eletrônica Direito e Política, Programa de Pós-Graduação Stricto Sensu em Ciência Jurídica da UNIVALI, Itajaí, v.14, n.1, $1^{\circ}$ quadrimestre de 2019. Disponível em: www.univali.br/direitoepolitica - ISSN 1980-7791

BONAVIDES, Paulo e ANDRADE, Paes de. História Constitucional do Brasil. 3 ed. Rio de Janeiro: Paz e Terra, 1991.

BORTOLON, Vanessa. A restrição do foro por prerrogativa de função e a força normativa da constituição em tempos de lava jato. Disponível em: https://www.conpedi.org.br/publicacoes/27ixgmd9/0141905o/14155UL53BH0Ou Bz.pdf. Acesso em: 30 de Abril de 2018.

BRASIL. Constituição da República dos Estados Unidos do Brasil de 1891. Disponível em: <http://www.planalto.gov.br/ccivil_03/constituicao/constituicao91.htm>. Acesso em: 03 nov 2016.

Disponível

Constituição da República dos Estados Unidos do Brasil de 1934. <http://www.planalto.gov.br/ccivil 03/constituicao/constituicao34.htm>. Acesso em: 03 nov 2016.

\section{7.}

Constituição dos Estados Unidos do Brasil de 10 de novembro de <http://www.planalto.gov.br/ccivil_03/constituicao/constituicao34.htm>. Acesso em: 03 nov 2016.

\section{6).}

Constituição dos estados unidos do brasil (de 18 de setembro de <http://www.planalto.gov.br/ccivil_03/constituicao/constituicao46.htm>. Acesso em: 03 nov 2016.

Constituição da República Federativa do Brasil de 1967. Disponível em: <http://www.planalto.gov.br/ccivil_03/constituicao/constituicao67.htm>. Acesso em: 03 nov 2016.

Constituição da República Federativa do Brasil de 1988. Disponível em: <http://www.planalto.gov.br/ccivil_03/constituicao/constituicao.htm>. Acesso em: 03 nov 2016.

CARDOSO, Sérgio. Retorno ao Republicanismo. Belo Horizonte: Editora UFMG, 2004.

Folha de São Paulo. "Ministro do STF defende fim do foro privilegiado". 26/02/2012, Caderno especial "Transparência"

GALVÃO, José Otávio. Três argumentos para manter o foro por prerrogativa de função. Disponível em: https://www.conjur.com.br/2017-mar04/observatorio-constitucional-tres-argumentos-manter-foro-prerrogativafuncao. Acesso em: 30 de Abril de 2018. 
BIASI, Lourenço; SANTOS, Samuel Martins dos. Prerrogativa de foro e jurisdição constitucional: uma análise em perspectiva histórica das mudanças jurisprudenciais do Supremo Tribunal Federal. Revista Eletrônica Direito e Política, Programa de Pós-Graduação Stricto Sensu em Ciência Jurídica da UNIVALI, Itajaí, v.14, n.1, $1^{\circ}$ quadrimestre de 2019. Disponível em: www.univali.br/direitoepolitica - ISSN 1980-7791

HABIB, Sérgio. Brasil: quinhentos anos de corrupção: enfoque sóciohistórico-jurídico-penal. Porto Alegre: Sergio Antonio Fabris Editor, 1994. 232.

PETTIT, Philip. Teoria da Liberdade. Renato Sérgio Pubo Maciel (Trad). Belo Horizonte: Del Rey, 2007.

SCHWARZ, Roberto. Cultura na Política. Rio de Janeiro: Paz e Terra, 2001.

SILVA NETO, Casimiro Pedro da. A construção da democracia: síntese histórica dos grandes momentos da Câmara dos Deputados, das Assembléias Nacionais Constituintes do Congresso Nacional. Publicador Câmara dos Deputados, Coordenação de Publicações. 2003

SILVA NETO, Casimiro Pedro da A $1^{\text {a }}$ República. 2009. Disponível em: $<$ http://www2.camara.leg.br/a-

camara/conheca/historia/historia/a1republica.html>. Acesso em: 26 ago 2017.

STRECK, Lenio Luiz / Morais,Jose Luis Bolzan de: Ciência Política e Teoria do Estado. $8^{a}$ edição. Livraria Do Advogado 2013, p.155.

SUPREMO TRIBUNAL FEDERAL. Ação Panal. AP. n. 937. Órgão julgador: Primeira Turma. Relator: Min. Luís Roberto Barroso. Data do início do julgamento: 31/05/2017. Disponível

http://portal.stf.jus.br/processos/detalhe.asp?incidente $=4776682$ Última visualização em 01 de junho de 2018 às 17:42.

SUPREMO TRIBUNAL FEDERAL. Inquérito Policial. IP. n. 4667. Órgão julgador: Primeira Turma. Relator: Min. Luís Roberto Barroso. Data do início do julgamento: 07/02/2018. Disponível

em: http://portal.stf.jus.br/processos/detalhe.asp?incidente $=5341961$, visualização em 01 de junho de 2018 às 17:42.

SUPREMO TRIBUNAL FEDERAL. Reclamação. Recl. n. 473/GB. Órgão julgador: Tribunal Pleno. Relator: Min. Victor Nunes Leal. Data do julgamento: 31/01/1962. Disponível http://redir.stf.jus.br/paginadorpub/paginador.jsp?docTP=AC\&docID $=87387$ Última visualização em 24 de novembro de 2017 às 01:52.

TAVARES FILHO, Newton. Foro por prerrogativa de função no direito comparado. Brasília: Câmara dos Deputados/consultoria Legislativa. Consultoria Legislativa da Câmara dos Deputados, 2015. Disponível em < http://www2.camara.leg.br/a-camara/documentos-e-pesquisa/estudos-e-notastecnicas/areas-da-conle/tema6/2015_21981_foro-por-prerrogativa-de-funcaono-direito-comparado_newton-tavares>. Acesso em: 19 set 2017.

TAVARES FILHO, newton. Foro privilegiado: pontos positivos e negativos. Consultoria Legislativa da Câmara dos Deputados, 2016. Disponível em http://www2.camara.leg.br/a-camara/documentos-e-pesquisa/estudos-e-notastecnicas/areas-da-conle/tema6/2016_10290_foro-privilegiado-pontos-positivose-negativos. Último acesso em: 09/05/2018 
BIASI, Lourenço; SANTOS, Samuel Martins dos. Prerrogativa de foro e jurisdição constitucional: uma análise em perspectiva histórica das mudanças jurisprudenciais do Supremo Tribunal Federal. Revista Eletrônica Direito e Política, Programa de Pós-Graduação Stricto Sensu em Ciência Jurídica da UNIVALI, Itajaí, v.14, n.1, $1^{0}$ quadrimestre de 2019. Disponível em: www.univali.br/direitoepolitica - ISSN 1980-7791

TOCQUEVILLE, Alexis: Democracia na América Leis e Costumes. Editora Martins Fontes. São Paulo. Edição 2. Ano 2005, pg. 290-291.

VERONESE, Osmar. Impunidade parlamentar. São Paulo: Revista dos Tribunais. 2002.

RECEBIDO EM: 11/10/2018

APROVADO EM: 22/02/2019 